\title{
Pragmatic Awareness of Iraqi undergraduate EFL Learners in using Request Strategies
}

\section{Nadhim Obaid Hussein ${ }^{1}$, Intan Safinas Mohd Ariff Albakri ${ }^{2 *}$, Goh Hock Seng ${ }^{3 *}$}

${ }^{1} \mathrm{Ph}$. D. Student, Faculty of Languages and Communication, University Pendidikan Sultan Idris, Kuala Lumpur, Malaysia

${ }^{2}$ Assistant ProfessorDr., Faculty of Languages and Communication, University Pendidikan Sultan Idris, Tg. Malim Perak, Malaysia

${ }^{3}$ Assistant Professor. Dr., Faculty of Languages and Communication, University Pendidikan Sultan Idris, Tg. Malim Perak, Malaysia

Corresponding author: NadhimObaid, E-mail: nadhimiraqi@yahoo.com

\begin{abstract}
The study explained English learners' pragmatic awareness of EFL learners in using request strategies, those strategies that they used in gaining pragmatic ability in academic and social communication. The paper was presented by a public programmer lead that prioritizes the necessity for English learners to develop their ability to use request successfully in social and academic communications. The study aimed to clarify the important role of strategies on improving learners' pragmatic awareness among Iraqi undergraduate EFL learners. Moreover, most English learners fail to present pragmatic ability on how to use request by relating utterances to their meanings, knowing the intention of language users. There is growing of studies on the effectiveness of strategies on increasing students 'pragmatic awareness in EFL college teaching.
\end{abstract}

Keywords - Pragmatic awareness, Request strategies, and EFL students.

\section{INTRODUCTION}

To communicate effectively in cross-cultural situations, EFL students should be able to use language suitably in the setting. Having a high level of pragmatic awareness can help EFL students in achieving effective communication in an EFL situation. In other words, Communication is an indispensable part of any community life in which learners feel the need to interact with each other for certain aims. It is through the concept of language that learners can communicate with a number of speakers in a variety of contexts (Hussein, Albakri, \&Seng, 2019). Thomas (1983) defines pragmatic competence as "the ability to use language efficiently in order to achieve a definite purpose and to understand the language in context" (p. 94). So, in order for students to communicate more proficiently in a foreign context, they should improve their pragmatic awareness through pragmatic awareness-raising tasks and activities needed to provide students with recognition of pragmatic aspects like speech acts namely using request strategies in a foreign context (SafontJorda, 2005). Moreover, pragmatics generally deals with what is beyond the dictionary meanings of statements; in other arguments, it is about what is truly meant with an utterance based on the norms and conventions of a particular society, or context, in which conversation takes place (Hussein, Albakri, \&Seng, 2019).
In the field of language pedagogy, the study on developing pragmatic competence of EFL students has attracted lots of attention. Unfortunately, one of the neglected issues in this field and interlanguage pragmatics (ILP) studies, as some scholars (Canale, 1983; Krasner, 1999; Kurdghelashvili, 2015, Hussein \&Albakri, 2019) stated that understanding only vocabulary or syntax is insufficient to be a competent language learner in the social or educational communication. An English learner considered as an excellent language learner may not be able to communicate with learners of the target language. Therefore, English learners need to comprehend and have communicative competence which includes both language competence and pragmatic competence for accomplishing communication among different nationalities in different settings. Language competence contains pronunciation, words, spelling, and sentence rules while pragmatic competence concerns learners' use of language and picking the suitable utterance in the given position (Leung, 2005).

Additionally, research by Hymes (1972) indicated that pragmatic competence is regarded as one of the major aspects of the teaching of communicative language in the EFL /ESL environments. A study was adopted by Bataineh and Hussein (2015) and Hussein, Albakri, \&Seng (2019) showed that pragmatic doesn't focus on grammatical knowledge or syntactic forms, but it focuses on the meaning 
of learners' language use in the acts of social or cultural communication, as well as it focuses on helping the learners to create meaning rather than improve perfectly grammatical structure or syntactic forms. As well as, a study by Hussein and Elttayef (2018) and Hussein, Albakri, \&Seng ( 2019) stated that EFL learners' pragmatic which is an aspect of communicative competence. Such pragmatic should be efficiently and purposefully chosen in such a way that they should be more testable, teachable, interesting, motivating in FL environments. Therefore, it plays a vital role in obtaining different cultures or different customs of the foreign language. Through pragmatic instruction, English students can obtain different socio-cultural languages and have pragmatic awareness then they can communicate easily in any place. Sometimes, EFL students show pragmatic competence when the written or spoken language produced is polite and socially suitable. Also, pragmatic competence is defined as the students' use of language and uses appropriate rules and politeness dictated by the way it is understood by the learner and express social or cultural requests (Koike, 1989). In order to achieve the aims of learners' communication in the schoolroom, and develop learners' pragmatic awareness in the EFL classroom. Hence, learners should recognize pragmatic instruction, specifically teaching request strategies that students employ in their utterances and find out new strategies employed by the students to achieve their communication objectives in different countries (Hussein \&Albakri, 2019; Hussein, Albakri, \&Seng, 2019). This may help foreign students become more pragmatically and socially aware of their own expressions, and provide understanding into language teachers in order to develop EFL learners' speech act of request in different situations.

\section{THE RESEARCH PROBLEM}

It was found that the main problem in EFL environments, particularly in the Iraq environment. EFL students in a college, seem to sometimes lack pragmatic awareness when trying to speak in English, which is their foreign language. As well as, our experience in teaching English as a foreign language in universities, and other educational institutions in Iraq has led me to believe that English language majors/graduates in Iraq have problems in using English for communication, not only in academic expressions but also even in situational conversions of street (Hussein \&Albakri, 2019; Hussein, Albakri, \&Seng, 2019). More importantly, although the increasing interest in teaching pragmatic in many procedures of studies, a little in-depth study has been conducted on the effects of teaching pragmatic on Iraqi EFL learners, where most of the foreign language teaching lacks adequate teaching pragmatic. Especially, there is no using the main strategies to facilitate communication among students (Hussein, Albakri, \&Seng, 2019; Hussein \&Albakri, 2019). As a result, Iraqi learners seem less communication in the social and academic requests when connecting in the English language; more especially when performing face-threatening acts (FTA). As well as, scholars in previous studies such as Cohen (1996) and Hussein \&Albakri, (2019) indicated that language students can have all of the syntactic context and lexical items and still not be able to communicate their message because they lack the necessary pragmatic awareness to communicate their intent. Although some Iraqi students seem pragmatically competent when speaking in the Arabic language, this competence is not necessarily reflected in their foreign language (Hussein \&Albakri 2019). Therefore, Iraqi students need to pragmatic awareness and how to use suitable strategies to permit them to be aware to communicate among different nationalities, and they also become more pragmatically and culturally aware of their own expressions (Hussein \&Albakri, 2019; Hussein, Albakri, \&Seng, 2019).

\section{THE AIM OF RESEARCH}

Recently, there has been little empirical research into clarification on the implication of request strategies on increasing EFL students' pragmatic awareness in the Iraqi context. A part of a Ph.D. dissertation, the present research aims to explain pragmatic awareness of Iraqi students in using request strategies in EFL University. Request strategy is one of the strategies that are popular in the area of pragmatics as it is more usually found in everyday learners' utterances in diverse situations (Hussein \&Albakri, 2019; Hussein, Albakri, \&Seng, 2019). It is the most produced utterance in the foreign language classroom setting. Therefore, using of request strategies made in the class may help Iraqi EFL learners to be aware of pragmatic in the EFL settings. Moreover, results of different researches (Ellis, 1992; Hill, 1997; Jalilifar, 2009; Hussein \&Albakri, 2019; Hussein, Albakri, \&Seng, 2019) that focused on the importance of request strategies on increasing English students' pragmatic awareness.

\section{REVIEW OF THE RELATED LITERATURE} 4.1 Earlier Researches on Pragmatics in EFL Learning and Teaching

In this part, different studies (Alcón-Soler, 2005; Rueda, 2006; Hussein \&Albakri, 2019) on pragmatics in EFL 
learning and teaching has stated that it is important to help language students to increase the production of request, and use request to communicate effectively in different environments. Moreover, empirical researches were adopted by Hussein and Elttayef (2018) and Hussein and Albakri (2019) indicated that EFL students pragmatic which is an aspect of communicative ability in the classroom. Such pragmatic should be successfully selected in such a way that they should be more testable, teachable, interesting, appealing in the FL classroom. Also, the empirical study adopted by Bataineh and Hussein (2015) and Hussein \&Albakri (2019) indicated that pragmatic doesn't focus on grammatical understanding, but it emphasizes the meaning of students' language use in the acts of communication in EFL schoolroom. The findings of those studies provided rich evidence to support the necessity for EFL students' request strategies to develop pragmatic awareness and rise the act of communication in the FL contexts.

Besides, various researches have discovered the role of pragmatic instruction on increasing English learners' pragmatic awareness in the EFL classroom (Bachman, 1990; Schmidt 1993; Bardovi-Harlig\& Hartford, 1997; Bataineh and Hussein, 2015; Hussein \&Albakri, 2019). An important research was adopted by Hussein, Albakri, \&Seng, (2019) and Hussein \&Albakri (2019) showed that syntactic development does not confirm an equivalent level of pragmatic ability, and even excellent learners may not be able to understand their intended objectives and contents in setting (Eslami- Rasekh, 2005). For instance, a language learner may pass any test or answer paper at any time, but they are not able to convey the same language appropriately in real-life circumstances because of the lack of awareness in pragmatic and don't have acts of communication. Furthermore, a study by Kasper (1989) and Hussein, Albakri, \&Seng, (2019) who stated that excellent learners' communicative acts normally had pragmatic failures and proposed that there was a need for teaching pragmatic to include pragmatic awareness by using different activities/tasks in daily lessons. Hence, the results of preceding studies discovered that pragmatic instruction has been identified as one of the significant teachings that help language students become effectively application in pragmatic awareness.

Basically, regarding pragmatic awareness in the teaching of language, a number of activities are valued for pragmatic awareness and can be classified into two main types: activities to increase students' pragmatic awareness all drills, and activities providing opportunities for communicative drills (Bardovi-Harlig\& Hartford, 1997; Hussein, Albakri, \&Seng, 2019; Hussein, Albakri, \&Seng, 2019). Regarding pragmatic awareness, activities are those that have been intended to grow recognition of how learners' language forms are utilized suitably in setting (Eslami- Rasekh, 2005). For instance, Schmidt's work (1993) states pragmatic awareness activities that include paying aware attention to related practices, their pragmalinguistic purposes and the sociopragmatic constraints these specific forms contain. Also, other activities that offer opportunities for communicative application may contain group work, in-class discussions and cultural communications outside the lesson. Hence, results revealed those two activities help to develop EFL students' pragmatic awareness.

\subsection{Earlier Researches Regarding Impact of Teaching} Pragmatic onIncreasing Learners' pragmatic awareness.

Former studies have been conducted to find out the importance of implication pragmatic instruction on developing students' pragmatic awareness, numerous researches had provided that the students were aware that learning strategies were a portion of their language learning pragmatic awareness, the results showed that the learners showed more usage of pragmatic awareness in performing of social or academic conversation (Yang, 1999; Hong-Nam and Leavell, 2006; Tuncer, 2009; Li, 2010; Alzeebaree \& Yavuz, 2017; Hussein \&Albakri, 2019; Hussein, Albakri, $\&$ Seng, 2019). Teaching pragmatic by using strategies were the most prioritized actions that helped on increasing students' pragmatic awareness in the EFL classes. Hence, the findings discovered that there was a statistically significant difference between the two groups (experimental and control) in the usage of strategies for developing pragmatic awareness.

Additionally, it was noted that teaching pragmatic aspects by using strategies helped language students improve their pragmatic awareness especially the usage of requests (Shridhar \& Shridhar, 1986, 1994; Sheorey, 1999; Alzeebaree \& Yavuz, 2017; Hussein, Albakri, \&Seng, 2019). Also, it was observed that strategies helped EFL students become more effective in their communicative circumstances. Besides, the learners' pragmatic awareness influenced some of the strategies they used. As well as, according to a study by Yang (1999) identified quantitative proof to find out English students' learning strategy in the context of an indigenized form of English. Also, different studies concentrated on teaching pragmatic by using strategies in language learning have exposed that language 
learning strategies are important to learners on improving their pragmatic awareness (Griffiths, 2003; Ersözlü, 2010; Li, 2010; Purdie \& Oliver 1999; Y1lmaz, 2010; Hussein, Albakri, \&Seng, 2019).

\section{CONCLUSION}

This study has presented the pragmatic awareness of learns in using request strategies in EFL college, as well as its explanations and characteristics of new procedures on developing learners' pragmatic awareness. It has revealed different studies on learners' pragmatic awareness in EFL learning. The studies display a consensus that pragmatic can be taught by using certain strategies in EFL learning and teaching helps language students. Furthermore, it has been declared that learners' different strategies that help to improve learners' pragmatic awareness, the results of the analysis revealed that there was a statistically significant difference in findings of the usage of strategies on increasing learners' pragmatic awareness. However, this summary also reveals that more investigation needs to be conducted in different studies to identify elements that may affect the way students go about pragmatic awareness, as well as the strategies, they apply to obtain pragmatic awareness. Finally, depending on the effective findings, the researcher tries to identify the role of strategies on developing learners' pragmatic awareness. Then, he tries to focus on suitable strategies for increasing pragmatic awareness in EFL College.

\section{REFERENCES}

[1] Alzeebaree, Y. \&Yavuz, M. (2017) Realization of the Speech Acts of Request and Apology by Middle Eastern EFL Learners. EURASIA Journal of Mathematics, Science and Technology Education ISSN: 1305-8223 (online) 1305-8215 (print).

[2] Alcón-Soler, E. (2005) 'Does instruction work for learning pragmatics in the EFL context?' System, 33(3), pp. 417-435. doi: 10.1016/j.system.2005.06.005.

[3] Bachman, L. (1990). Fundamental consideration in language testing. New York: Oxford University Press.

[4] Bardovi-Harlig, K., \&Dörnyei, Z. (1997). Pragmatic awareness and instructed L2 learning: An empirical investigation. Paper presented at the AAAL 1997 Conference, Orlando.

[5] Bardovi-Harlig, K., \& Hartford, B. (1997). Beyond methods: Components of second language teacher education. New York: McGraw-Hill.

[6] Bataineh, A. \& Hussein, N. (2015). The effect of using webcam chat on the undergraduate EFL students' pragmatic competence. International Journal of education. ISSIN 19484576. VO.7.NO.2.

[7] Bremner, S. (1998). Language learning strategies and language proficiency: Investigating the relationship in Hong Kong. Asian Pacific Journal of Language in Education, 1(2), 490-514.

[8] Byram, M. (Ed.). (2000). Routledge encyclopedia of language teaching and learning.

[9] London and New York: Routledge. Procedia Social and Behavioral Sciences, 2(2), 5147-5151.

[10] Canale, M. (1983). From communicative competence to language pedagogy. In J. Richards \& R. Schmidt (Eds.), Language and Communication (pp. 2-27). London: Longman.

[11] Cohen, A. D. (1996). Developing the ability to perform speech acts. Studies in Second Language Acquisition, 18, 253-267.

[12] Eslami-Rasekh, Z. (2005). Raising the pragmatic awareness of language learners. ELT Journal, 59(3), 199-208.

[13] Ersözlü, Z. N. (2010). Determining of the student teachers" learning and studying strategies. Oxford: Oxford University Press.

[14] Eslami-Rasekh, Z. (2005). Raising the pragmatic awareness of language learners. ELT Journal, 59(3), 199-208.

[15] Ellis, R. (1992). The study of second language acquisition. Oxford: Oxford University Press.

[16] Green, J., \& Oxford, R. L. (1995). A closer look at learning strategies, L2 proficiency, and gender. TESOL Quarterly, 29(2), 261-297.

[17] Griffiths, C. (2003). Patterns of language learning strategy use. System, 31(3), 367-383.

[18] Hill, T. (1997). The development of pragmatic competence in an EFL context. Dissertation Abstracts International, 58, 3905.

[19] Hong-Nam, K., \&Leavell, A. G. (2006). Language learning strategy use of ESL students in an intensive English learning context. System, 34(3), 399-415.

[20] Hussein, N and Elttayef, A (2018). The effect of authentic materials on developing undergraduate EFL students' communicative competence. Journal of literature, Languages and linguistic .ISSI 2422-8535.

[21] Hussein, N \&Albakri, I (2019). Iraqi Learners' Problems in Learning Speech Act of Request in EFL Classroom. Journal of Education and Practice. ISSN 2222-1735 (Paper) ISSN 2222-288X (Online) DOI: 10.7176/JEP Vol.10, No.4.

[22] Hussein, N \&Albakri, I (2019). The Essential Role of Teaching Pragmatic in the Iraqi EFL Classroom. Journal of Education and Practice. ISSN 2222-1735 (Paper) ISSN 2222288X (Online) DOI: 10.7176/JEP Vol.10, No.4, 2019.

[23] Hussein, N, .Albakri, I (2019). The importance of the speech act of request in the Iraqi EFL classroom. International Journal of English Research ISSN: 2455-2186. Volume 5; Issue 2; Page No. 95-98. 
[24] Hussein, N., Albakri, I., \&Seng, G. (2019) . Pragmatic Competence and Activity-Based Language Teaching: Importance of Teaching Communicative Functions in Iraq EFL Context.International Journal of English, Literature and Social Science (IJELS). Vol-4, Issue-6, ISSN: 2456-7620.

[25] Hussein, N., Albakri, I., \&Seng, G. (2019). Usage of Speech Act of Request among Iraqi Male and Female Undergraduate EFL Students.International Journal of English, Literature and Social Science (IJELS).Vol-4, Issue-6, ISSN: 2456-7620.

[26] Hymes, D. (1972). On communicative competence. In J. B. Pride \& J. Holmes (Eds.), Sociolinguistic (pp.269-285). Harmon sworth: Penguin.

[27] Jalilifar, A. (2009). Request strategies: Cross-sectional study of Iranian EFL learners and Australian native speakers. English Language Teaching, 2,461.

[28] Kasper, G. (1989). Variation in interlanguage speech act realization. In S. Gases, C. Madden,

[29] Krasner, I. (1999). The role of culture in language teaching. Dialog on Language Instruction, 13(1-2), 79-88.

[30] Koike, D.A. (1989). Pragmatic competence and adult L2 acquisition: Speech acts in interlanguage. The Modern Language Journal, 73(3), 279-289.

[31] Kurdghelashvili, $T$ (2015) Speech Acts and Politeness Strategies in an EFL Classroom in Georgia. World Academy of Science, Engineering and Technology International Journal of Cognitive and Language Sciences .Vole: 9, No: 1

[32] Leung, C (2005).Convivial communication: decontextualizing communicative competence. International Journal of Applied Linguistics, vo.15, no.2, 119-144.

[33] Liu, A. (2010). On pragmatic "borrowing transfer" evidence from Chinese EFL learners' compliment response behavior. Chinese Journal of Applied Linguistics, 33(4), 26-44.

[34] Oxford, R. L. (1993). Research on second language learning strategies. Annual Review of Applied Linguistics, 13, 175-187.

[35] Oxford, R. L., \&Nyikos, M. (1989). Variables affecting choice of language learning strategies by university students. Modern Language Journal, 73, 404-419.

[36] Purdie, N., \& Oliver, R. (1999). Language learning strategies used by bilingual school-aged children. System, 27(3), 375388.

[37] Rueda, Y. (2006) 'Developing pragmatic competence in a foreign language', Colombian Applied Linguistics Journal, 8, pp. 169-182.

[38] SafontJordà, M. P. (2005). Third Language Learners: Pragmatic production an awareness. Clevedon: Multilingual Matters.

[39] Schmidt, R. (1993). Consciousness, learning and interlanguage pragmatics. In G. Kasper

[40] Sheorey, R. (1999). An examination of language learning strategy use in the setting of an indigenized variety of English. System, 27(2), 173-190.
[41] Shridhar, K., \&Shridhar, S. (1986). Bridging the paradigm gap: Second language acquisition theory and indigenized varieties of English. World Englishes, 5, 3-14.

[42] Thomas, J. (1983). Cross cultural pragmatic failure. Applied Linguistics, 4, 91-112.

[43] Tuncer, U. (2009). How do monolingual and bilingual language learners differ in use of learning strategies while learning a foreign language? Evidences from Mersin University. Procedia Social and Behavioral Sciences, 1(1), 852-856.

[44] Vellenga, H. (2004). Learning pragmatics from ESL and EFL textbooks: How likely? TESL- Electronic Journal, 8(2), 1-18.

[45] Verschueren, J. (1999). Understanding pragmatics. London, New York, Sydney: Arnold.

[46] Yang, N. D. (1999). The relationship between EFL learners' beliefs and learning strategy use. System, 27(4), 515-535.

[47] Yılmaz, C. (2010). The relationship between language learning strategies, gender, proficiency and self-efficacy beliefs: A study of ELT learners in Turkey. Procedia Social and Behavioral Sciences, 2(2), 682-687. 